\title{
Impact of Environmental Awareness on the Purchase of Green Products
}

\author{
Effulgence \\ Vol. 16 (Special Issue) \\ January - June, 2018 \\ Rukmini Devi Institute of Advanced Studies \\ E-mail : effulgence@rdias.ac.in, Website : www.rdias.ac.in \\ http://effulgence.rdias.ac.in/user/default.aspx \\ https://dx.doi.org/10.33601/effulgence.rdias/v16/iSpl1/2018/article0.1
}

\section{Ms. Shivangi Agarwal ${ }^{1}$ \\ Dr. Varsha Khattri ${ }^{2}$}

\begin{abstract}
A growing awareness of different environmental issues has resulted in a change in the way consumers look after their lives. There has been a change in consumer attitudes toward green lifestyle. People are actively trying to reduce their impact on the environment. However, this is not widespread and is still evolving. The issue of the environment is an important subject today, as almost every government and society has begun to be more aware of the problems related to it. This leads to a green marketing trend used by the company as one of the strategies to protect the environment and simultaneously gain profit. It is a phenomenon that has become an important concept and strategy to facilitate sustainable development in India. This research provides a review of environmental issues and identifies the green values of consumers, their level of awareness of environmental issues, products and environmental practices. This study further, highlights consumers' perceptions and preferences of green marketing practices and products using a structured questionnaire and the way their changing preferences have led to the evolution of green marketing.
\end{abstract}

Keywords: Environment protection, Environmental awareness, environment friendly, green marketing, green products, consumer awareness.

\section{INTRODUCTION}

$\mathrm{E}$ nvironmental problems are the main reasons for the emergence of green marketing and green products. According to the American Marketing Association (2001), "Green marketing is marketing products that are presumed to be safe for the environment". Green marketing refers to the process of selling products and services based on their environmental benefits. Such a product or service may be environment friendly. It is produced and packaged in an environment friendly manner (Katait, 2014). Thus, green marketing incorporates a wide range of activities, including product modification, changes to the production process, changes in packaging, and modification of advertising (Tiwari, 2007). Green marketing refers to the concept of holistic marketing in which the product, marketing consumption on the elimination of products and services proceed in a manner which is less harmful to the environment, with an increasing awareness of the implications of global

1. MBA Student, Amity Business School, Amity University, Noida

2. Assistant Professor, Amity Business School, Amity University, Noida 
warming, non-biodegradable solid waste, harmful impacts of pollutants etc. (Thapa, 2014). As a result, traders and consumers are increasingly sensitive to the need to switch to green products and services. Company houses and traders have to turn their whole business into green, as rule, rather than as an option, to improve society and human welfare to increase profit (Dutta, 2017).

In addition, consumers have become increasingly aware of their environmental approaches, desires and purchases, which have led to increased incentives for consumers to purchase environment friendly products and services. They are more concerned about environmental issues and are considering buying more environment friendly products, even if they have to purchase at higher prices. Consumers are more interested in the importance of the natural environment and understand that their buying behaviour in production and consumption will have a direct impact on the environment. As a result, the growing number of consumers aiming to buy environment friendly products paves many opportunities for companies that use "green" or "environmentally friendly" elements as part of their value proposition. Companies that provide products manufactured and designed with a blend of environmental marketing have a stable competitive advantage.

Thus, the idea of green marketing is based on consumers' take on environmental friendly products (Tiwari, 2007). Therefore, it is necessary to further investigate the awareness and behaviour of consumers' towards environment protection, green marketing and green products.

It is cumbersome to define green products. However based on different definitions of green marketing, some common characteristics of green products are:

1. Products which are energy efficient (both in use and in production).

2. Products which are water efficient (both in use and in production)

3. Products with Low emission (low emission of pollutants).

4. Products which are safe and healthy

5. Recyclable products

6. Sustainable products

7. Biodegradable products

8. Re-used products.

9. Products which are third party certified to the public or transportation standard (eg certified organic and certified wood)

10. Renewable products

\section{LITERATURE REVIEW}

The literature review enumerates the views regarding the importance of green marketing and green products, environment measures taken by the people to protect our planet Earth and various factors influencing the customers' decision in purchasing green products.

\section{Importance of Green marketing and Green products}

Tiwari (2007) discussed the importance of green marketing and the evolution of it. She stated that there are three phases which led to the evolution of green marketing. The first phase of green marketing stated green marketing as "ecological" which highlighted the various marketing activities which can lead to decrease in the environmental problems. Then, in the second phase she stated the green marketing as "environmental" which focused on the technology to provide innovative environment friendly products and then in the third phase, she stated green marketing as "sustainable" in which green marketing was referred to the production of products which are safer to the environment.

FuiYeng \& Yazdanifard (2015) stated that green products are a brand value for the companies. As a by-product, these companies have a competitive advantage. It is a win- win situation for both the companies and the consumers. Companies can give the brand value to its green products and can also sell them at higher prices and on the other hand, the 
purchase of such products gives the consumers a chance to contribute towards environment by being "environmental friendly."

Thapa (2014) analyzed that green marketing is an environmental protection tool for the future generation. It has a positive impact on environmental safety. Factors considered important for the same are price, the environment approach, cognition and conviction and marketing approach. It further suggested that the green marketing approach can be improved as a tool for environmental protection if these factors are taken into account. Green marketing offers opportunities for innovation and helps make people more eco-responsible. Green marketing has proved effective making changes in consumer behavior and inspiring them to buy environmental friendly products. It was clear from the findings and analysis that while eco-responsible attitudes have increased, but a large group of consumers still lack "green" knowledge because of low awareness.

Banerjee (2007) analyzed that the Green Consumer will continue to attract as environmental consciousness changes time. The results of studies from previous years will not necessarily be valid in the future. New search on this topic should aim to identify possible developments in consumer attitudes, intentions and behaviors. It would be interesting to undertake studies assessing the keys to success in the environmental design process and launch strategies, based on previous studies applied to the development of new traditional products process.

\section{Factors affecting consumers' decisions to buy green products}

Saxena (2008) investigated through the questionnaire with sample size of 180 respondents that the consumers' awareness and the purchase of green products are positively related to each other. Consumers are willing to purchase the green products only when they are aware of it deeply. So, thus they highlight the importance of various marketing programs which should be focused on increasing consumer awareness towards environmental problems, green marketing and hence, the green products.

Harun (2014) states the importance of green advertising in influencing the consumers to purchase green products. Consumers are willing to purchase green products in the future as well, even if they are costly, but this will only happen when they will be aware of it. Khan (2013) states that though consumers are aware of environmental problems, but still there is a diffusion to buy green products. It further states that there is a gap between consumers concerns towards environment and their actual purchase of such products.

Dutta (2017) contemplates on price as an important factor while purchasing green products. They highlight the fact that even the strong supporters of environment protection are hesitant to buy green products if they are not cost effective. Kagopour (2017) studied various factors that influence the consumers to buy products. He found out that green marketing and eco- friendly products are one of the most important decision factor which influences their decision to buy green products.

Reis (2013) discussed the preference of green products with regards to gender discrimination. The study indicated that there are no significant differences between men and women regarding their skepticism of environmental claims in green advertisements. However, further analysis of the study showed that men were more skeptical towards green products than women.

\section{Environment protection measures}

Soonthonsmai (2007) discussed about green consumers. He states that green consumers are the one who are aware of environmental problems and take steps towards protecting the environment. They are the ones who are willing to buy green products 
because as far as they find them convenient, affordable and have good performance. And further, the study reinforces that consumer awareness is the most important thing which regulates consumers' behaviour towards environment protection.

Bhatia (2013) stated that there is lack of consumer awareness about green initiatives taken by both government and non- government activities and at the same time consumers are not aware of the various benefits of green products. Thus various initiatives should be taken to highlight the importance of green marketing and green products. Lakhan (2000) iterated that it is the attitude/ selfconcept of the consumers which regulate their behaviour towards environment protection. If they have the attitude of preserving the environment and really want to do something for the protection and preservation of their planet, then they are the ones who are more inclined towards the purchase of green products. Shaikh (2011) reiterates the importance of environment education among our upcoming future generation to protect the environment. It further discusses that the environmental problems have perverse dimensions, thus, public participation processes are appropriate approaches to deal with them.

\section{RESEARCH METHODOLOGY}

The study follows the following methodology:

\section{Problem Statement}

Increasing pollution and environmental damage from traditional production methods have led to the marketing of green products. In general, these products become relatively expensive and also face low consumer awareness. Therefore, in order to know the level of acceptance of green products in the Indian market (especially Delhi NCR), it is important to investigate the market of green products.

\section{Objectives of the study:-}

1. To study the importance of environment protection and explore the various measures taken by the people to protect environment.

2. To assess the awareness and inclination of consumers towards green products.

3. To identify the reasons for both the purchase and non- purchase of green products by consumers.

\section{Sampling Method and Technique}

The study included the close ended questionnaire which contained the questions testing various variables regarding the green marketing and its products. It also included the consumers' attitude towards environment protection and the various measures taken by them to protect our planet, Earth. This research further also helped to know the importance of green marketing and its products among today's youth and also it helped to find out the various factors which prevents the consumers from purchasing green marketing products. The number of respondents who participated in this research were 117. This research was constrained to Delhi NCR. The age of the respondents varied between $24-50$ with $78.5 \%$ belonged to the 20-35 years of age and $15 \%$ belonged to the $35-50$ years of age. Further, this sample represented both the genders, different groups of education level, marital status and income level, with the majority $(75.8 \%)$ of the population belonging to the young age group of people. Convenient sampling was taken as the sampling method, as it was considered to be the best, inexpensive and suitable method for such type of research. (Thapa, 2014). 


\section{Demographics profile:-}

\begin{tabular}{|c|c|c|c|}
\hline Age & frequency & percentage & cumulative percentage \\
\hline $18-25$ & 91 & $78 \%$ & $78 \%$ \\
\hline $25-40$ & 19 & $16 \%$ & $94 \%$ \\
\hline more than 40 & 7 & $6 \%$ & $100 \%$ \\
\hline \multicolumn{4}{|l|}{ Gender } \\
\hline female & 80 & $68 \%$ & $68 \%$ \\
\hline male & 37 & $32 \%$ & $100 \%$ \\
\hline \multicolumn{4}{|l|}{ Profession } \\
\hline Student & 86 & $74 \%$ & $74 \%$ \\
\hline businessman & 4 & $3 \%$ & $77 \%$ \\
\hline service & 1 & $1 \%$ & $78 \%$ \\
\hline housewife & 26 & $22 \%$ & $100 \%$ \\
\hline
\end{tabular}

\section{DATA ANALYSIS AND INTERPRETATION}

For this particular research with 117 respondents, hypothesis is been created to test the consumers' behaviour towards environment protection, green marketing and the green products. The entire data collected through questionnaire is been tabulated, coded and analysed through chi-square test to check the accuracy of non- parametric variables in the questionnaire. Then the tables along with percentages were used to analyse the measures taken by the people to protect the environment, factors which prevent them from buying green products

Hypothesis 1: Consumers have the positive attitude towards environment protection

Hypothesis 2: Consumers are aware about the green products

Hypothesis 3: Consumers have the positive attitude towards purchase of green products

Hypothesis 4: Consumers perception towards environmental condition effects their attitude regarding purchase of green products

The questionnaire was divided into two parts: First part had likert scale questions which included the questions to test their attitude towards environment protection and green products. In such questions, the respondents has to choose between "yes", "And then the other part of the questionnaire was both open ended and close ended, where the respondents can select either out of the options regarding their way of protecting Earth and the reason for purchase or nonpurchase of the green products or they could also write their own way for the same. In this paper, first the hypothesis will be tested through chi-square, correlation, t-paired sample test and then the various factors and measures will be analysed for the same.

Hypothesis 1: This is created to test consumers' awareness towards harmful effects towards the environment. For this, two questions were asked which could predict the behaviour of our respondents towards our planet, Earth. Through this research it was found out that $95.4 \%$ of the respondents were completely aware about the harmful effects caused to our planet and also they want to protect it from its various harmfulness. 3.1\% responded "maybe", as they may or may not be aware of the harmful effects and $2.1 \%$ are not aware. This is also tested through chi-square as follows:-

Hypothesis Test Summary

\begin{tabular}{|c|c|c|c|c|}
\hline & Null Hypothesis & Test $\Leftrightarrow$ & Sig. $\triangleq$ & Decision \\
\hline 1 & $\begin{array}{l}\text { The categories of VAR00001 occur } \\
\text { with equal probabilities. }\end{array}$ & $\begin{array}{l}\text { One-Sample } \\
\text { Chi-Square } \\
\text { Test }\end{array}$ & .000 & $\begin{array}{l}\text { Reject the } \\
\text { null } \\
\text { hypothesis. }\end{array}$ \\
\hline
\end{tabular}

Asymptotic significances are displayed. The significance level is .05 . 


\begin{tabular}{|l|r|}
\hline Test Statistic & 167.333 \\
\hline Degrees of Freedom & 3 \\
\hline Asymptotic Sig. (2-sided test) & .000 \\
\hline
\end{tabular}

The null hypothesis will be rejected as the value of chi- square alpha i.e. 7.815 is less than the teststatistic of chi-square i.e. 167.33 and thus, this proves our alternate hypothesis i.e. H1and it proves that the consumers' have the positive attitude towards the environment protection and they want to protect their planet.

Measures to protect the environment- Through the questionnaire, it was also found out that what actions/measures are taken by the consumers to protect the environment and how much they contribute to Swacch Bharat movement. According to Marcin (2016), sustainable development and to deplete the use of over- exploitation of nonrenewable source of energy is the best way to preserve our planet. Thus, it was found out that:

\begin{tabular}{|l|l|l|}
\hline By planting trees & 28 & $24.6 \%$ \\
\hline $\begin{array}{l}\text { By educating people regarding } \\
\text { the importance of environment } \\
\text { protection }\end{array}$ & 51 & $44.6 \%$ \\
\hline By preventing pollution & 61 & $52.3 \%$ \\
\hline By purchasing green products & 39 & $33.8 \%$ \\
\hline $\begin{array}{l}\text { By not throwing garbage on the } \\
\text { roads }\end{array}$ & 90 & $77.8 \%$ \\
\hline
\end{tabular}

Thus, this shows that consumers try to protect the planet mostly by not throwing garbage on the roads $(77.8 \%)$. But, at the same time they also try to protect the planet by educating other people and preventing other people in harming the environment (52.3\%) and also by preventing pollution (44.6\%). As of now, respondents do not prefer much buying of green products as only $33.8 \%$ preserve environment by purchasing such products. Though, all the above measures are important to protect to the environment and all should be executed by the consumers seriously. Thus, people should start planting trees and should start purchasing green products to preserve the environment more effectively.

Hypothesis 2:- This is created to test the consumers' awareness towards green marketing and green products. And further, it was also tested that in what respect the consumers are aware about the green products and green marketing. Through this research, it was found out that $79 \%$ of the respondents were aware of the green products and the remaining $21 \%$ respondents are not aware of the green products at all. This is further tested through chi-square test as follows:-

\begin{tabular}{|c|c|c|c|c|c|}
\hline \multicolumn{6}{|c|}{ Hypothesis Test Summary } \\
\hline & Null Hypothesis & Test & $\Delta$ & Sig. $\triangleq$ & Decision $\nabla$ \\
\hline 1 & $\begin{array}{l}\text { The categories defined by } \\
\text { VARO0008 }=N O \text { and YES occu } \\
\text { with probabilities } 0.5 \text { and } 0.5 \text {. }\end{array}$ & $\begin{array}{l}\text { One-Samp } \\
\text { Binomial } \\
\text { Test }\end{array}$ & & .000 & $\begin{array}{l}\text { Reject the } \\
\text { null } \\
\text { hypothesis. }\end{array}$ \\
\hline
\end{tabular}

Asymptotic significances are displayed. The significance level is .05 .

\begin{tabular}{|lr|}
\hline Test Statistic & 12.000 \\
\hline Standard Error & 4.031 \\
\hline Standardized Test Statistic & -4.961 \\
\hline Asymptotic Sig. (2-sided test) & .000 \\
\hline
\end{tabular}


Thus, through the above chi-square table it can be seen that the chi- square alpha value 5.991 is less than test statistic i.e. 12, due to which the null hypothesis is rejected and also as .05>.000 is also proves that the null hypothesis is rejected and the alternate hypothesis i.e. $\mathrm{H} 2$ is accepted. Therefore, it proves that consumers have the positive attitude and are aware about the green products and green marketing.
Now, further this research also helped to found out the consumers awareness towards green products on various aspects. Consumers had the option of agreeing on more than 1 option but less than 3 . The option available to them were regarding the awareness of green marketing and green products caused to health, environment, or through various brands. Thus, it concluded as follows:-

\begin{tabular}{|l|l|l|}
\hline Benefits to health & 43 & $36.75 \%$ \\
\hline Benefits to environment & 59 & $50.42 \%$ \\
\hline Through various brands & 8 & $6.83 \%$ \\
\hline Not aware & 7 & $5.98 \%$ \\
\hline
\end{tabular}

Thus, this shows that consumers are most aware about green products and green marketing in terms of the benefits caused to the environment by them (50.42\%). Consumers are also aware about green products in terms of the benefits which are provided by green products to our health (36.75\%). While, very less are aware about the brands which provide the green products $(6.83 \%)$.

Hypothesis 3: This is created to test consumers' attitude towards purchase of green products. Through the questionnaire, consumers were educated about the green products and then their analysis was done to know that once they have become aware about the green products, now whether or not they will be willing to purchase such products. To this, $79.4 \%$ agreed that they would like to purchase such products, while $20.6 \%$ would not still not like to buy such products. Consumers' attitude towards purchase of green products was also tested through chi-square test as follows:-

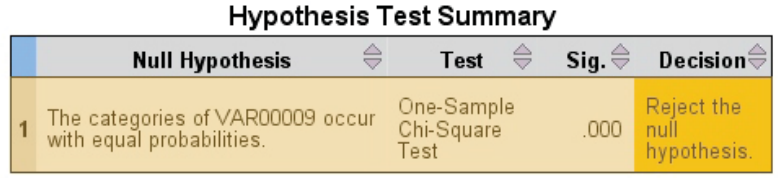

Asymptotic significances are displayed. The significance level is .05

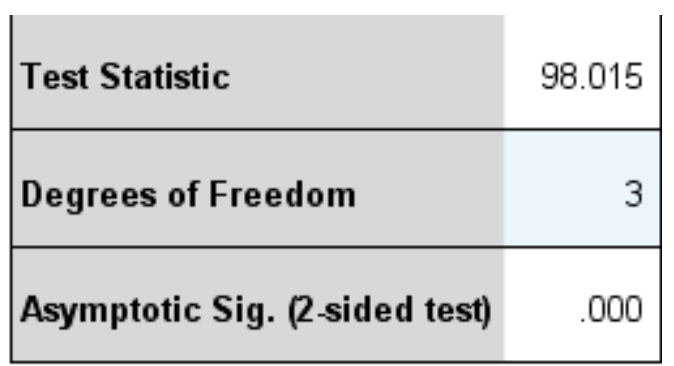

Thus, in the above chi- square table the value of chisquare alpha 7.815 is less than the t- statistic i.e. 98.015 which rejects the null hypothesis and also the value of $.05>.000$ which further rejects the null hypothesis and accepts the alternate hypothesis i.e. H3. Therefore, it proves that the consumers have the positive attitude towards the purchase of green products and green marketing.

Hypothesis 4: This is created to test that whether the consumers awareness towards environment and the attitude of the consumers' towards green products are directly correlated or not. For this, t-sample test for the paired samples was taken. One variable was the consumers' awareness towards environment and the other variable was their attitude towards green products. And the results were as follows:- 


\begin{tabular}{|c|c|c|c|c|}
\hline \multicolumn{5}{|c|}{ Paired Samples Correlations } \\
\hline & & $\mathrm{N}$ & Correlation & Sig. \\
\hline Pair 1 & VAR00010 \& VAR00011 & 2 & 1.000 & .000 \\
\hline
\end{tabular}

Paired Samples Test

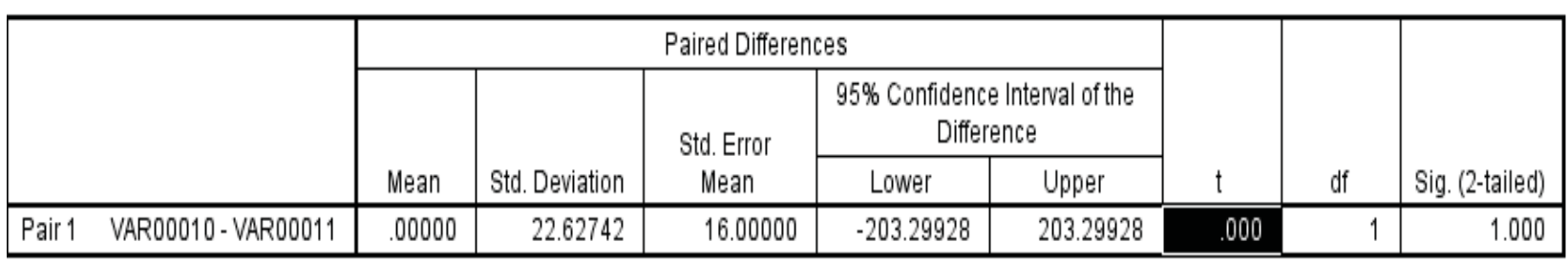

Thus, as the value of the t-statistic is less than the significance value i.e. $.000<.05$, due to which the null hypothesis will be rejected and the alternate hypothesis i.e. H4 will be accepted. As a result, this test proves that with the positive std. deviation and the positive correlation proves that both the variables are correlated with each other. The more is the awareness about the harmful effects of the environment the more will be the products purchased by the consumers.
Factors influencing the purchase of green products - After educating the customers on green marketing and green products through questionnaire, the respondents were asked to analyse the various reasons due to which they would like to buy green products. The respondents were allowed to select up to 2 responses out of the given. The analysis was as follows:

\begin{tabular}{|l|c|c|}
\hline They are healthy & 58 & $49.2 \%$ \\
\hline $\begin{array}{l}\text { They are environment } \\
\text { friendly }\end{array}$ & 109 & $93.8 \%$ \\
\hline They add to the social status & 4 & $3.1 \%$ \\
\hline $\begin{array}{l}\text { They are attractive and their } \\
\text { packaging can be reused }\end{array}$ & 5 & $4.6 \%$ \\
\hline
\end{tabular}

The above table depicts the mean reason for the respondents to buy green products is that the green products are environment friendly (93.8\%). This, further also shows that though the consumers may be aware about the harmful effects caused to the environment but still they want to purchase them because of some other reasons also. As the above table shows that $95 \%$ of the respondents agreed that they are aware about the harmful effects caused to the environment, but still $93 \%$ wants to purchase them because they are environment friendly. And rest of the respondents want to purchase them because they are healthy (44\%), add to the social status $(3.1 \%)$ and are attractive $(4.6 \%)$. Thus, it is important for the consumers to think more about the environment.

Factors which prevents consumers to buy green products - Following is an account of the same:

Thus, it was found out that because of the unavailability of such green products, consumers are not able to purchase green products. Further, promotion $(44.6 \%)$ of green products is equally important. When people are not fully aware about such products, then they will definitely be reluctant to buy such products which reduces their confidence (15.4\%) over the time. Their lack of variety (39.6\%) 


\begin{tabular}{|l|c|c|}
\hline expensive & 25 & $21.5 \%$ \\
\hline Not readily available & 57 & $49.2 \%$ \\
\hline Not aware of its benefits & 8 & $7.7 \%$ \\
\hline Not promoted properly & 51 & $44.6 \%$ \\
\hline Lack of confidence & 18 & $15.4 \%$ \\
\hline $\begin{array}{l}\text { Not available in full range of } \\
\text { variety }\end{array}$ & 46 & $39.6 \%$ \\
\hline
\end{tabular}

makes them expensive too $(21.5 \%)$ and reduces the choices for the consumers to buy the products, thereby making other products more attractive. As a result, to make the consumers purchase such green products as much as environment and green marketing education is important equally is the readiness, price, variety, right and effective advertisements of green products are important.

\section{RESULTS AND DISCUSSIONS}

The growing environmental issues and the concern for the society and regulatory environment led the researchers to investigate about the consumers' inclination about it. The sample base which consisted of the youth to middle age group of people showed their great concern towards the environment. The consumers are aware about the issues and the harmful effects of the environment. Further, they were also aware about the green products but exactly didn't know how it could benefit the environment. Once, they were educated about it they were ready to purchase the product with the main reason that it will help to protect the environment.

It was analysed that the consumers' awareness about the environment and the purchase of green products are positively correlated with each other. The main drawbacks are that the green products are not readily available with lack of awareness about them. It fails to help consumers build their trust over them and thereby, preventing them from buying such products. Once, the green products will be readily available in all the cities on India with variety and good promotional activities, consumers will start purchasing them.

\section{MANAGERIAL IMPLICATIONS}

To achieve environment sustainability, it is necessary to make significant changes. For this, the various products and resources which help in protecting the environment need to be delivered properly. It could help both the environment and the society at large. The study found that green marketing is an environmental protection tool for the future generation, which has a positive impact on environment safety. The null hypothesis: "The perception of the consumers regarding the environmental conditions has a positive impact on the purchase of green products" has been proven true. Factors considered useful are the lack of availability of green products, lack of promotional activities for green products, lack of awareness about green products and the environmentally conscious approach and marketing approach. The green marketing approach can be improved as a tool for environmental protection if these factors are taken into account. Green marketing offers opportunities for innovation and helps make people more ecofriendly and responsible. Green marketing has proved effective making changes in consumer behaviour and inspiring them to buy environmentally friendly products. It is clear from the above findings that environmentally friendly attitudes have increased, but a large number of consumers still lack "green" knowledge due to low 
consumer awareness. So, initiatives must be taken to educate customers about green products and green marketing by keeping the various factors in to consideration so that people can become more ecoresponsible and environmental friendly for the preservation of the earth. The government should monitor CSR policies and mandate a green marketing policy to protect the environment. Price sensitivity shows that green products are safe and affordable and therefore, the consumers are willing to pay the high price if this is applicable. Environmental awareness proves green product is the tool for the environment protection.

\section{REFERENCES}

1) Banerjee, S. (2007). Environmental Marketing (Green Marketing Rudiments). IOSR Journal of Business and Management (IOSR-JBM), 69. Retrieved from http: / / www.iosrjournals.org/iosr$\mathrm{jbm} /$ papers/7th-ibrc-volume-2/24.pdf

2) Bhatanagr, V. (2012). An environmental protection tool: green marketing and its effect onc umser buying behaviour. international journal of emerging research in maangement and technology ISSN:2278-9359.

3) Bhatia, M. (2013). Green Marketing: A Study of Consumer Perception and Preferences in India. Electronic green journal, 36. Retrieved from file:/ / C:/Users/This\%20PC/Downloads/eSch olarship\%20UC\%20item\%205mc39217.pdf

4) Dutta, N. (2017). Lip Service or Real Concern: Testing the Claim to Pay Premium for Green Products through an experimental research. Summer AMA. Retrieved from https://web.a.ebscohost.com/ehost/pdfviewer / pdfviewer?vid=34\&sid=c7e794e2-67df-4ba4bb7c-2feca614e1c8\%40sessionmgr4009

5) Harun, A. (2014). THE INFLUENCE OF CONSUMERS' PERCEPTION OF GREEN PRODUCTS ON GREEN PURCJASE INTENTION. INnternational journal of asian social science, 924. Retrieved from http://www.aessweb.com/pdf-files/ijass-2014- 4(8)-924-939.pdf

6) Juwaheer. (2005). Emerging shades of green marketing conscience among the populaion of a small island economy- A acse study on mauritius. $\quad$ Retrieved from http://irfd.org/events/wfsids/virtual/papers/ sids_tdjuwaheer.pdf.

7) Kagopour, M. (2017). Studying the Effects of Environmental Commitments on Green marketing strategies. International Journal of Economic Perspectives, 11. Retrieved from https://web.a.ebscohost.com/ehost/pdfviewer / pdfviewer?vid=56\&sid=c7e794e2-67df-4ba4bb7c-2feca614e1c8\%40sessionmgr4009

8) KATAIT, D. S. (2014). GREEN MARKETING IN INDIA AND ITS IMPACT ON CONSUMER BEHAVIOUR. ISSN 0976-2183, 5, 12. Retrieved $\mathrm{f} \quad \mathrm{r} \quad \mathrm{o} \quad \mathrm{m}$ https://web.a.ebscohost.com/ehost/pdfviewer / pdfviewer?vid=37\&sid=c7e794e2-67df-4ba4bb7c-2feca614e1c8\%40sessionmgr4009

9) Keller. (1987). Industry and the environment: toawrds a new philsophy (Vol. 54). Vital speeches.

10) khan, m. (2013). A study on Consumers attitudes towards green products and green marketing. International Journal of Advanced Trends in Computer Science and Engineering, 2, 6. Retrieved from http://www.warse.org/pdfs/2013/spicetem201 351.pdf

11) Kong, W. (2014). THE INFLUENCE OF CONSUMERS' PERCEPTION OF GREEN PRODUCTS on Green purchase Intention. International Journal of Asian Social Science, 924-939. Retrieved from https:/ / www.researchgate.net/profile/Jaratin_ Lily/publication/266739008_The_Influence_of_ Consumers_Perception_of_Green_Products_on_ Green_Purchase_Intention/links/54800d3f0cf25 b80dd703da4/The-Influence-of-ConsumersPerception-of-Green-Products-on-Green-Pur

12) Kotler, P. (1994). Marketing management analysis, planning, implementation and control. prentice hall . 
13) lakhan, C. V. (2000). Environmental Protection Efforts in a Developing Country: The Case of Guyana. Electronic green journal. Retrieved $\begin{array}{llll}\mathrm{f} & \mathrm{r} & \mathrm{O} & \mathrm{m}\end{array}$ https:/ / escholarship.org/content/qt86f3q49b/q t86f3q49b.pdf

14) Marcin, A. (2016). ECONOMIC PROCESSES MANAGEMENT. international scientific ejournal (ISSN 2311-6293). Retrieved from https://web.b.ebscohost.com/ehost/pdfviewer / pdfviewer?vid=4\&sid=d6b2f1f7-ace1-45189575-32079c8530c7\%40sessionmgr104

15) Muhmin, A. (2007). Exploring consumers' willingness to be environmentally freindly. International Journal of Consumers Studies, 31.

16) Reis, R. (2013). FACTORS AFFECTING SKEPTICISM TOWARD GREEN ADVERTISING. Journal of advertising, 41. Retrieved from https://web.a.ebscohost.com/ehost/pdfviewer / pdfviewer?vid=51\&sid=c7e794e2-67df-4ba4bb7c-2feca614e1c8\%40sessionmgr4009

17) Saxena, R. P. (2008). Consumer attitude towards green marketing: an exploratory study. University of Wollongong in Dubai - Papers.

18) Shaikh, A. S. (2011). Consumer Perceptions of Green Products: A surevy of Karachi. Journal of Independent Studies and Research MSSE V, 9, 158. Retrieved from file:/ / C:/Users/This\%20PC/Downloads/1107 MSSE02.pdf

19) SHALINI THAPA, S. V. (2014). ANALYSIS OF GREEN MARKETING AS ENVIRONMENT PROTECTION TOOL: A STUDY OF CONSUMER OF DEHRADUN. ISSN 0976-2183, $5 . \quad$ Retrieved from https://web.a.ebscohost.com/ehost/pdfviewer / pdfviewer?vid=6\&sid=6f299485-27eb-4d938fea-66df07079324\%40sessionmgr4010

20) Soonthonsmai. (2007). environmental green amrekting as global competitve edge:concept, synthesis, and implication. EABR (Business) and ETLC (Teaching) Conference.

21) Tiwari, J. (2007). Green marketing in India : An overview. IOSR Journal of Business and
Management (IOSR-JBM), 33-40. Retrieved from http: / / www.iosrjournals.org/iosr$\mathrm{jbm} /$ papers/ncvbm/volume-1/6.pdf

22) Yazdanifard, W. F. (2015). Green Marketing: A Study of Consumers' Buying Behavior in realtion to green products. Global Journal of Management and Business Research: marketing, Volume 15 Issue 5 . Retrieved from https:/ /globaljournals.org/GJMBR_Volume15/ 2-Green-Marketing-A-Study.pdf 